\title{
Prosody as an argument for a layered left periphery ${ }^{1}$
}

\author{
Karen De Clercq \\ Ghent University/FWO \\ karen.declercq@ugent.be
}

\section{Introduction}

Van Heuven and Haan $(2000,2002)$ did experimental work investigating the functional hypothesis that phonetic/prosodic interrogativity marking is stronger in inverse proportion to the (number of) lexico-syntactic markers used for the expression of a particular question type. If statements (ST) are taken as the unmarked structure, wh-questions (WH) signal interrogativity by means of both inversion and a wh-word, yes/no- questions (YN) by means of inversion alone and declarative questions (DE) have no special lexico-syntactic means to signal interrogativity. Hence, the functional hypothesis was that the prosodic signalling of interrogativity would be stronger for DE-questions, less so for $\mathrm{YN}$-questions and even less so for WH-questions, as illustrated by the sequence in (1).

(1) $\mathrm{DE}>\mathrm{YN}>\mathrm{WH}>\mathrm{ST}$

Van Heuven and Haan's experimental research confirmed this hypothesis. Interestingly, a closer look at how clause typing is encoded in syntax and more in particular within cartography (Rizzi 1997, Cinque 1999, Haegeman 2012), indicates that the hierarchy in (1) is also present in syntax. More concretely, increased prosodic interrogativity marking seems to go hand in hand with the activation of more syntactic structure. From a syntactic point of view the results from these phonological experiments can be read $1^{\circ}$ as an extra argument for a cartographic or layered approach to the left periphery and $2^{\circ}$ as an incentive to further research on the syntax-prosody interface, more in particular on the extent to which functional projections are visible in the mapping from syntactic to prosodic structure (Selkirk 2011, Elfner 2012). In what follows I contribute mainly to the first point and I discuss how the prosodic sequence in (1) is reflected in the functional hierarchy in syntax.

\section{Clause typing and the left periphery}

\section{1. $\mathrm{CP}$}

Chomsky and Lasnik (1977) suggest that every clause needs to be typed in syntax. Clause typing of interrogatives has been argued to be encoded in $C^{\circ}$ (see Katz and Postal 1964, Baker 1970, Bresnan 1972, Cheng 1991), either due to the presence of a Q particle or due to movement of a wh-constituent to SpecCP. For YN-questions, it is usually assumed that finite verbs move to $\mathrm{C}^{\circ}$; in wh-questions the wh-word in addition also moves to SpecCP. The 
derivation for a sample wh-question Wat kocht Jan 'What did John buy?' in Dutch is given in (2).

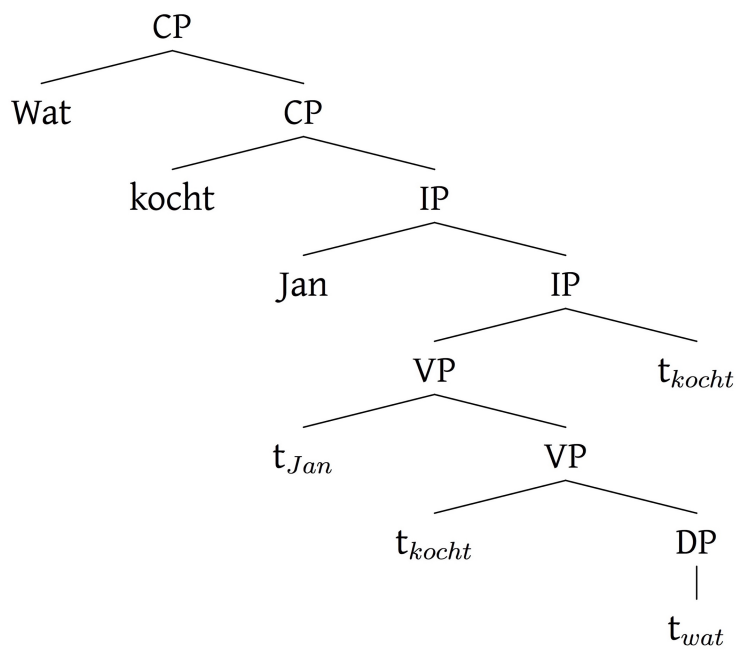

(2)

However, with this take on CP it is hard to account for data like those in (3) (from my own Flemish dialect), where at least two complementizers can be used in a main clause, and it is nearly impossible to capture data with a subordinated clause like those from Strijen Dutch, (4). In (4) the complementizers of and dat are separated by a wh-constituent met wie, thus making it impossible to treat them as one complex complementizer hosted by $\mathrm{C}^{\circ}$ (van Craenenbroeck 2010:32-33).

(3) En of dat hij er zin in heeft! And if that he r-pron pleasure in has 'For sure he feels like it!' (Aalst, author's dialect)

(4) Ik weet nie of met wie dat Jan oan et proate was. I know not if with who that John on it talk.INF was 'I don't know who John was talking to.'

Data like (3) and (4) suggest that more positions are available in the left periphery of a clause. However, before I come back to the Dutch data in (3) and (4), I make a little detour to Italian, for which Rizzi $(1997,2001)$ proposed a split CP.

\subsection{Rizzi's split CP}

Rizzi $(1997,2001)$ proposes to split CP into different layers, visualized in the tree structure in (5). 


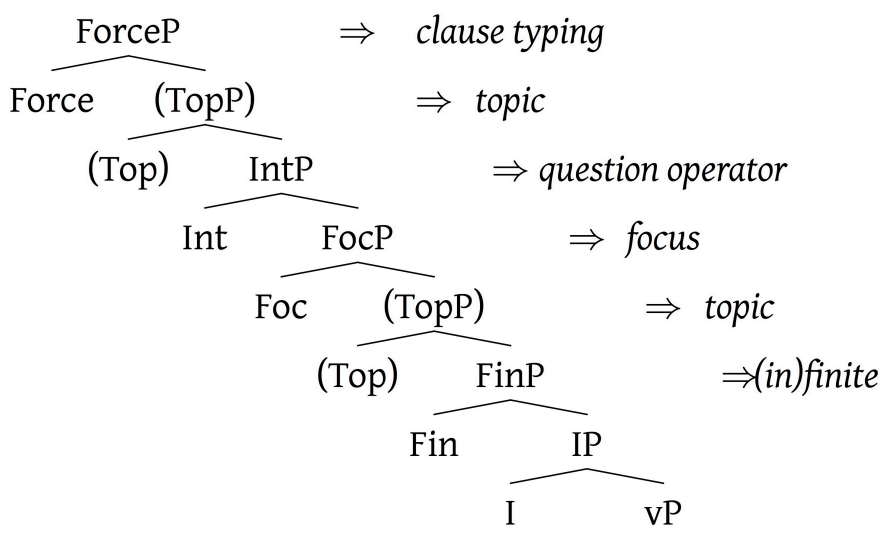

(5)

In this structure, ForceP, which hosts Italian che 'that' (but not Dutch 'dat', cf. below), is the layer dedicated to clause typing. However, this position is not always overtly filled, since clause typing can also happen via lower positions interacting with Force ${ }^{\circ}$. ForceP mediates between the surrounding discourse and the propositional content expressed in IP. FinP is a layer reflecting the (non)finiteness of the propositional content expressed in IP. In between these layers Rizzi (1997) argues there is a Focus Phrase, hosting focalised constituents or wharguments, and two optional positions for topicalized constituents. By means of these focus and topic layers, Rizzi (2001: 289-91) was able to identify an extra layer, Interrogative Phrase (IntP), in the left periphery. This layer hosts the subordinate complementizer se 'if' in Italian, and is responsible for $\mathrm{YN}$-questions. Che 'that' and se 'if' can both be followed, but not preceded, by a focus phrase, as in (6)-(7) respectively.

(6) a. Credo che QUESTO avreste dovuto dirgli (non qualcos'altro). 'I believe that THIS you should have said to him, not something else.'

b. *Credo QUESTO che avreste dovuto dirgli (non qualcos'altro). 'I believe THIS that you should have said to him, not something else.'

(7) a. Mi domando se QUESTO gli volessero dire (non qualcos'altro). 'I wonder if THIS they wanted to say to him, not something else.'

b. *Mi domando QUESTO se gli volessero dire (non qualcos'altro). 'I wonder THIS if they wanted to say to him, not something else.'

However, se 'if' can be followed and preceded by a topic, (8), while this is not possible for che 'that' (9). Che 'that' can only be followed by a topic (9).

(8) a. Mi domando se questi problemi, potremo mai affrontarli. 'I wonder if these problems, we will ever be able to address them'

b. Mi domando, questi problemi, se potremo mai affrontarli.

'I wonder, these problems, if we will ever be able to address them'

(9) a. Credo che a Gianni, avrebbero dovuto dirgli la verità.

'I believe that to Gianni, they should have said the truth to him' 
b. *Credo, a Gianni, che avrebbero dovuto dirgli la verità.

'I believe, to Gianni, that they should have said the truth to him'

On the basis of these data Rizzi concludes that se 'if' is the head of IntP, a position below ForceP hosting a question operator in between two optional TopPs.

The one-layered CP we started out with has hence been split up in four functional projections (FinP, FocP, IntP and ForcP) and two optional topic positions.

\subsection{A split CP for Dutch}

In line with proposals by Hoekstra and Zwart (1994, 1997), Bennis $(1997,2000)$ and Van Craenenbroeck (2010), who - in spite of using different labels - all argue for a split CP in Dutch, I want to suggest that of 'if' heads IntP, met wie 'with who' is in SpecFocP and (following Haegeman 1996) dat 'that' is in Fin', as in (10):

$$
\text { [Forcep [IntP [Of] [ FocP met wie [ FinP [dat] [TP hij dat leuk vindt ]]]] }
$$

Moreover, I want to hypothesize that the sentence in (3) provides even more support for the richly layered CP as proposed by Rizzi and more in particular for the presence of Force ${ }^{\circ}$ in Dutch. Without en 'and' the sentence in (3) becomes sharply ungrammatical as an exclamation, as exemplified by (11a), whilst being perfectly grammatical as a question, (11b).
a. ${ }^{*}$ Of dat hij er
if that he r-pron
zin in
heeft!
pleasure in
has
b. Of dat hij
If that he
er zin
r-pron
pleasure
in heeft?
'Whether he finds joy in it?'

$E n$ is hence not a regular coordinator in (3), but types the clause in a crucial way as an exclamative clause, a fact which is explained by putting it in Force ${ }^{\circ}$. The fact that without en the clause gets typed as a YN-interrogative, follows naturally if of if' is in Int $^{\circ}$, the position dedicated to $\mathrm{YN}$-questions. Putting these observations together, we arrive at the structure in (12) for the left periphery of the clause in (3):

$$
\text { [Forcep [ En] [IntP [of] [ FocP [ FinP [dat] [TP hij er zin in heeft]]]]] }
$$

With Rizzi's sequence in place and after applying it to Dutch, it becomes clear that part of the sequence in (1), namely $\mathrm{YN}>\mathrm{WH}>\mathrm{ST}$, which was established on the basis of prosody, is also part of the functional sequence, as illustrated in (13). 


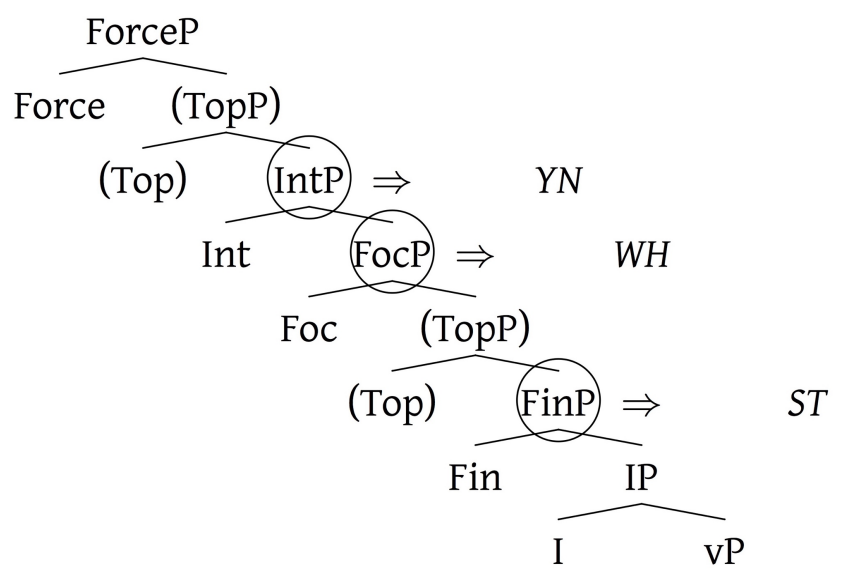

(13)

IntP is activated in $\mathrm{YN}$-questions, FocP in $\mathrm{WH}$-questions and FinP in regular declarative statements. ${ }^{2}$ The only type of question Rizzi's left periphery does not tackle is the DEquestion. In the next section I explore this type of question.

\section{Beyond CP: a speech act layer}

In this section I argue that DE-questions activate a speech act layer on top of the complex $\mathrm{CP}$, which is responsible for the speaker-hearer relations, and which hosts pragmatic particles.

The Dutch particle hé 'isn't it' is compatible with DE-questions, but incompatible with ST, $\mathrm{YN}$ and $\mathrm{WH}$, as shown in (14). In other words, this question particle shares a property with DE-questions that the other clause types do not have.
a. *De bus vertrekt, hé.
ST
b. *Aan welke halte vertrekt de bus, hé? WH
c. *Vertrekt de bus aan halte 5 , hé?
YN
d. De bus vertrekt aan halte 5 , hé?
DE

Van Heuven and Haan (2003) define this property of hé as a confirmation seeking property. In experimental research they found 1) that YN is information seeking, 2) that DE can be used to seek confirmation or information and 3) that the presence of hé in a DE-question turns this question into an exclusively confirmation-seeking question. In other words, DE can either fulfil the information seeking role of $\mathrm{YN}$, or a different confirmation seeking role, which it systematically realizes in the presence of the question particle hé. Given that we already know which projection needs to be activated for a YN-question, a closer look at hé will shed more light on which part of the structure is involved in DE-questions.

\footnotetext{
${ }^{2}$ In line with Starke (2004: 260-262) I assume that all features of the functional sequence are always present for the interpretative component (LF), but that unmarked values, like [-wh], [-neg], [-foc], can be dropped in syntax due to the fact that they are interpretatively recoverable.
} 
Question particles like hé bring us to how clause type interacts with speech acts and to how speech acts are encoded in syntax. Ross (1970) proposed the following deep structure for a sentence like I have a dog, Fout! Verwijzingsbron niet gevonden..

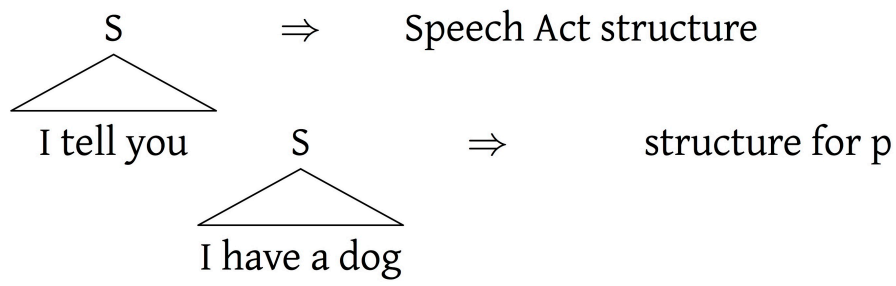

(15)

Recent research by Speas and Tenny (2003), Hill (2013), Haegeman and Hill (2013) and Heim et al (2014) revives Ross' hypothesis. Haegeman \& Hill (2013) discuss data from West Flemish (WF) that show that particles like nè $(m)$, wè , zé/zè establish a relationship between speaker and hearer, either in terms of attention-seeking or bonding (Haegeman and Hill 2013: 372-373). For this reason, they call them speech act particles. Attention seeking particles, like zé, have a rising intonation, come in clause initial and clause final position, (16a) and (16e), whilst particles like zè, with falling intonation, come exclusively in clause final position (16b-d-e). Zè has an evidential reading.

(16) a. Zé, Valère is doa! zé Valère is there 'Look, Valère is there!'

b. Valère is doa zè.

Valère is there zè

'Valère is there, as you see.'

c. *Zè, Valère is doa.

d. Zé, Valère is doa zè.

e. Valère is doa zè, zé.

f. *Valère is doa zé, zè.

Haegeman and Hill (2013:383) show that speech act particles are main clause phenomena, cf. (17), and that when in initial position the particles occur before the finite verb, (18).
a. *Je zei [ né dat da roare was].
Hesaid né that that strange was
'He said that was strange.'
b. Je zei [dat da roare was] né.

a. Né, dienen medalie een me 
né that medal have we

'There we are, the medal is ours.'

These data suggest that speech act particles must be part of a high layer in the extended left periphery of main clauses. Haegeman and Hill (2013) propose that there is a Speech Act Phrase (SAP) on top of Rizzi's ForceP, which can itself be divided into two different layers.

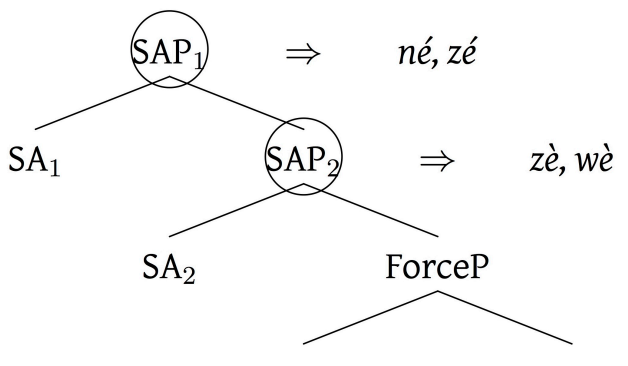

(19)

Following Hill (2007) they assume that the lower layer is hearer related and the upper layer speaker related. The lower layer hosts the particles with a falling intonation contour, the upper one those with a rising contour. Support for this analysis comes from the fact that particles with falling intonation and rising intonation can co-occur, as shown in (16d-e) above, but two particles with rising or falling intonation cannot co-occur, (20).

(20) a. Né, men artikel is gedoan wè (*zé).

b. *Men artikel is gedoan wè (*zè) (né).

Haegeman and Hill (2013:376) emphasize that there is a difference between clause typing particles and the particles they discuss. Nevertheless, even if they do not type the clause, there is often a connection between the speech act particle and a particular clause type. We made a similar observation for Dutch hé, which selects the DE- clause type but does not type the clause as DE. Moreover, also hé is a main clause phenomenon, i.e. it cannot occur in embedded sentences.

(21) *Ik hoorde hé dat de bus aan halte 5 vertrekt?

Adopting these two layers, we can now assume that DE-questions with hé activate the speaker related confirmation seeking SAP1-layer, and DE-questions in their information seeking role the SAP2-layer. The tree in Fout! Verwijzingsbron niet gevonden. illustrates how the entire prosodic sequence in (1) is mirrored in the functional sequence. 


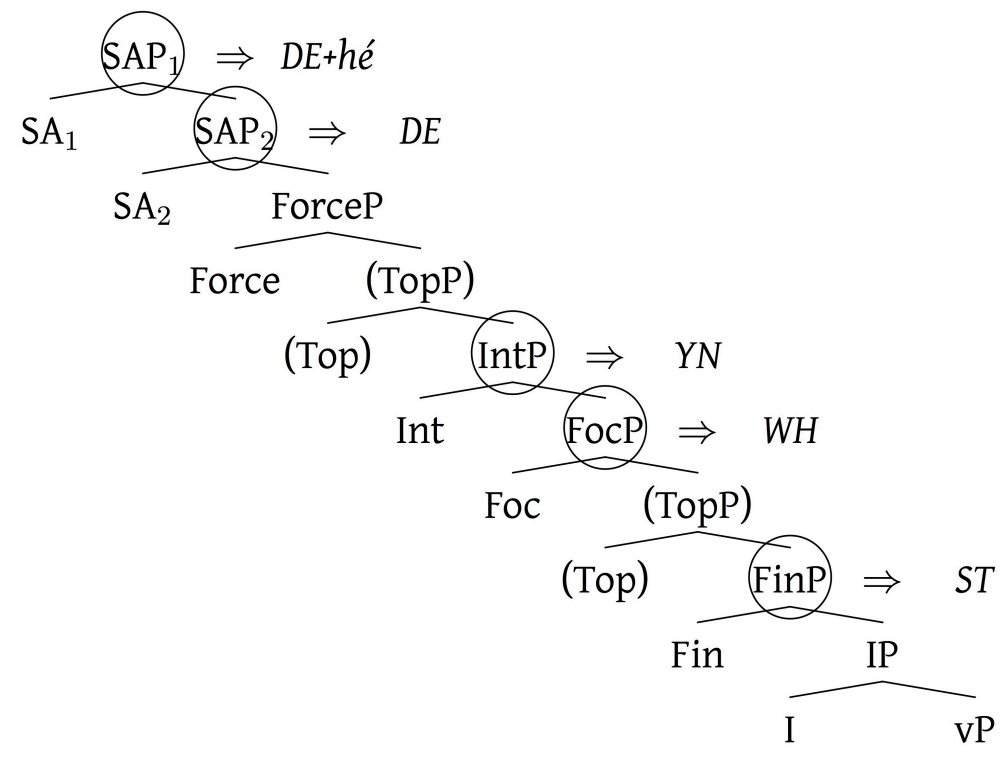

(22)

Obviously, this observation raises many different questions and further issues. Still, the parallel between the hierarchy established on prosodic grounds, given in (1) above, and the syntactic hierarchy in (22), is striking. A more detailed study of the syntax-prosody interface may well shed more light on this intriguing parallel.

\section{References}

Baker, Carl Lee (1970). Notes on the Description of English Questions, Foundations of Language 6, 197-219.

Bennis, Hans (1997). Voegwoordvariaties. In A. van Santen and M. van der Wal, Taal in tijd en ruimte. Leiden: SNL. 353-364.

Bennis, Hans (2000). On the interpretation of functional categories. In: H. Bennis; M. Everaert, and E. Reuland (eds.), Interface strategies. Amsterdam: KNAW. 37-53.

Bresnan, Joan (1972). Theory of Complementation in English Syntax, PhD Dissertation. MIT. Cinque, Guglielmo (1999). Adverbs and Functional Heads. Oxford: Oxford University Press. Cheng, Lisa (1991). On the typology of wh-questions. PhD dissertation. MIT.

Chomsky, Noam \& Howard Lasnik. (1977). Filters and control. Linguistic Inquiry 8:425-504. Craenenbroeck, Jeroen van (2010). The syntax of ellipsis. Evidence from Dutch dialects. Oxford: Oxford University Press.

Elfner, Emily (2012). Syntax-prosody interactions in Irish. PhD dissertation. University of Massachusetts, Amherst.

Haan, Judith and Heuven Vincent J.J.P. (2003). This is a yes/no question?. In: P. Fikkert and L. Cornips (eds.), Linguistics in the Netherlands 2003. Amsterdam: John Benjamins. 59-70.

Haegeman, Liliane (1996). Verb Second, the Split CP and initial null subjects in Early Dutch finite clauses. Geneva Generative Papers 4: 133-175.

Haegeman, Liliane (2012). Adverbial clauses, main clause phenomena and the composition of the left periphery: the cartography of syntactic structures. Oxford: Oxford University Press. 
Haegeman, Liliane and Hill, Virginia (2013). The syntactization of discourse. In: R. Folli, C. Sevdali and R. Truswell (eds.), Syntax and its limits. Oxford Studies in Theoretical Linguistics. Oxford: Oxford University Press. 370-390.

Heuven Vincent J.J.P. van \& Haan Judith (2002). Temporal distribution of interrogativity markers in Dutch: A perceptual study. In: C Gussenhoven and N. Warner (eds.), Laboratory Phonology 7. Berlin: Mouton de Gruyter. 61-86.

Heuven Vincent J. van \& Judith, Haan. (2000). Phonetic correlates of statement versus question intonation in Dutch. In: A. Botinis (ed.), Intonation, analysis, modelling and technology. Dordrecht: Kluwer, 119-143.

Hoekstra, Eric and Zwart, Jan-Wouter C. (1994). De structuur van de CP: Functionele projecties voor topics en vraagwoorden in het Nederlands. Spektator 23: 191-212.

Hoekstra, Eric, and Zwart, C. Jan-Wouter (1997). Weer functionele projecties. Nederlandse Taalkunde 2: 121-132.

Hill, Virginia (2007). Vocatives and the pragmatics-syntax interface. Lingua 117: 2077-2105.

Katz, Jerrold and Postal, Paul (1964). An integrated theory of linguistic descriptions.

Cambridge, Massachusetts: MIT press.

Rizzi, Luigi (1997). The fine structure of the left periphery. In: Liliane Haegeman (ed.), Elements of Grammar: Handbook of Generative Syntax. Dordrecht: Kluwer. 281-339

Rizzi, Luigi (2001). On the position "int(errogative)" in the left periphery of the clause. In: G. Cinque and G. Salvi, Current studies in Italian syntax: Essays offered to Lorenzo Renzi. Amsterdam: Elsevier. 267-296.

Ross, John R. (1970). On Declarative Sentences. In: R. A. Jacobs and P. S. Rosenbaum (eds.), Readings in English Transformational Grammar. Waltham, Mass.: Ginn. 222-277.

Selkirk, Elisabeth (2011). The syntax-phonology interface. In: J. Goldsmith, J. Riggle and A. Yu (eds.), The Handbook of Phonological Theory, 2nd edition.

Starke, Michal (2004). On the inexistence of specifiers and the nature of heads. In Structures and beyond, ed. Adriana Belletti, volume 3, 252-268. Oxford: Oxford Uni- versity Press.

Speas, Peggy and Tenny, Carol (2003). Configurational properties of point of view roles. In: A-M. Di Sciullo (ed.), Asymmetry in grammar. Amsterdam: John Benjamins. 315-344.

Wiltschko, Martina and Heim, Johannes (2016). The Syntax of confirmationals: a neo performative analysis. In: G. Kaltenböck, E. Keizer and A. Lohmann (eds.), Outside the Clause. Form and function of extra-clausal constituents. Amsterdam: John Benjamins. 303-340.

Karen De Clercq

Ghent University/ Postdoctoral research fellow FWO

Blandijnberg 2

9000 Gent

karen.declercq@ugent.be 